\title{
$\begin{array}{lllllllllllllllll}\mathbf{R} & \mathbf{O} & \mathbf{Z} & \mathbf{P} & \mathbf{R} & \mathbf{A} & \mathbf{W} & \mathbf{Y} & \text { I } & \text { A } & \mathbf{R} & \mathbf{T} & \mathbf{Y} & \mathbf{K} & \mathbf{U} & \mathbf{L} & \mathbf{Y}\end{array}$
}

Prawo Kanoniczne

63(2020) nr 1

DOI:10.21697/pk.2020.63.1.01

\author{
KS. JÓZEF WROCEŃSKI SCJ \\ Wydział Prawa Kanonicznego \\ Uniwersytetu Kardynała Stefana Wyszyńskiego w Warszawie \\ ORCID: 0000-0003-4817-9196
}

\section{UTRATA URZĘDU PROBOSZCZA}

Treść: Wstęp. - 1. Rezygnacja z urzędu. - 2. Usunięcie - 2.1. Postępowanie w sprawie usunięcia proboszcza. - 2.2. Skutki usunięcia proboszcza.3. Przeniesienie. - 3.1. Postępowanie w sprawie przeniesienia proboszcza. - 3.2. Skutki przeniesienia proboszcza. - 4. Pozbawienie urzędu. - 5. Śmierć proboszcza. - 6. Upływ czasu. - 7. Skutki utraty urzędu proboszcza. - Zakończenie.

\section{Wstęp}

Sprawowanie urzędów kościelnych, w tym urzędu proboszcza jest wypełnianiem obowiązków lub zadań na korzyść Ludu Bożego, czyli dla „zbawienia dusz”, dlatego tytulariusz urzędu, powinien tak długo sprawować go, jak długo jego odpowiedzialna służba jest owocna. Nie można przy tym lekceważyć osobistych uprawnień tytulariusza, ale nie można też ich stawiać ponad dobro wspólnoty, której on służy². Ustawodawca kodeksowy problematykę utraty urzędu ujął w rozdziale II, tytuł IX w kan. 184-196. Nie podał on definicji utraty urzędu

\footnotetext{
${ }^{1}$ Por. Codex Iuris CAnonici auctoritatae Joannis Pauli PP. II promulgatus. Kodeks Prawa Kanonicznego, przekład polski zatwierdzony przez Konferencję Episkopatu, Pallottinum 1984, kan. 1752 (dalej KPK/83). Norma tegoż kanonu ukazuje zbawienie dusz jako najwyższe prawo Kościoła.

${ }^{2}$ Por. M. Żurowski, Problem władzy i powierzania urzędów w Kościele katolickim, Kraków 1984, s. 250.
} 
kościelnego, jednak ogólnie można ją sformułować, jako zdarzenie prawne, którego następstwem jest opróżnienie urzęduํ. Zdarzenie to jest zależne od woli tytulariusza urzędu lub przełożonego, kiedy indziej dokonuje się mocą samego prawa lub faktu. Skutki prawne utraty dotykają wprost tytulariusza, bowiem traci on prawa i obowiązki związane z urzędem i winien go opuścić oraz urzędu, który staje się wakujący. Pośrednio dotyczą też władzy, której przysługuje prawo jego nadawania ${ }^{4}$.

Względna stałość na urzędzie proboszcza określona kryterium „dobra dusz” sprawia, że parafia może być pozbawiona swojego pasterza na kilka sposobów. Może on najpierw sam poprosić o zwolnienie z pełnionych obowiązków, gdy uzna, że czas jego posługiwania w parafii się wypełnił. W tym przypadku rezygnacja może mieć miejsce, gdy mają zastosowanie obiektywne kryteria, jak choroba powodująca utratę zdolności do wykonywania urzędu czy określony przez prawodawcę wiek emerytalny lub też w sytuacji subiektywnie ocenionej za wystarczającą przyczynę takiej decyzji. Jeszcze inną formą utraty urzędu jest przeniesienie, co zazwyczaj jest poprzedzone rezygnacją zaleconą lub wymuszoną, albo uzyskaną na drodze porozumienia $z$ biskupem diecezjalnym. Może on również zostać zwolniony z obowiązków związanych z urzędem proboszcza wbrew swojej woli w przypadku, gdy zachodzą okoliczności określone prawem, które przewiduje w takiej sytuacji specjalną procedurę. Bardziej radykalną formą zwolnienia $\mathrm{z}$ obowiązków proboszcza jest pozbawienie go urzędu mocą samego prawa, dekretem administracyjnym lub na drodze postępowania sądowego. Procedury administracyjne są przewidziane przez ustawodawcę kodeksowego w księdze VII w kan. 1740-1752 lub sądowe w kan. 1717-1731. Wreszcie parafie bywają opróżniane w sposób naturalny, tzn. przez śmierć proboszcza, o ile w czasie choroby nie złożył on rezygnacji. Niniejsze opracowanie zmierza do

\footnotetext{
${ }^{3}$ Por. E. Sztafrowski, Podręcznik prawa kanonicznego, t. I, Warszawa 1985, s. 272.

${ }^{4}$ Por. R. Sobański, Utrata urzędu kościelnego, w: Komentarz do Kodeksu Prawa Kanonicznego, t. I, red. J. Krakowski, Pallottinum 2003, s. 274.
} 
omówienia sposobów utraty urzędu proboszcza i analizy szczegółowych kwestii prawnych z nimi związanych.

\section{Rezygnacja $z$ urzędu}

Rezygnacja, czyli zrzeczenie się wykonywania obowiązków proboszcza parafii jest regulowana najpierw przepisami ogólnymi odnoszącymi się również do innych urzędów w Kościele. Ustawodawca kodeksowy, mając na względzie racje obiektywne jak i subiektywne, które mogą sprawić, iż sprawowanie urzędu staje się ciężarem dla tytulariusza lub powoduje nieefektywność jego posługi, daje mu możliwość złożenia rezygnacji ${ }^{5}$, czyli świadomego i dobrowolnego zrzeczenia się powierzonego urzędu dla słusznej racji, zgodnie z przepisami prawa ${ }^{6}$. Rezygnacji, może więc dokonać każdy, kto jest poczytalny, o ile przemawia za tym słuszna przyczyna. Tak więc, rezygnacja zgodnie z prawem powinna być dokonana w pełni władz umysłowych, tym samym nie mogą jej złożyć ci, których stan psychiczny, choćby przejściowo jest taki, że rezygnacja nie może być im poczytana jako czyn świadomy ${ }^{7}$. Musi być też dobrowolna. Nie będzie ona ważna, gdy w tym przypadku proboszcz dokona jej pod wpływem ciężkiej i niesprawiedliwej bojaźni lub przymusu, jak też, gdy będzie podjęta na skutek podstępu, względnie błędu istotnego ${ }^{8}$. Ponadto musi być wolna od symonii dokonanej przez rezygnującego lub przyjmującego, ewentualnie przez osoby trzecie na korzyść wyżej wymienionych ${ }^{9}$. Ze względu na dobro ogólne rezygnacja osiąga swój skutek dopiero w momencie, gdy zostanie przyjęta przez nadającego urząd. A zatem rezygnacja $z$ urzędu proboszcza powinna być złożona na ręce biskupa diecezjalnego na piśmie albo ustnie wobec dwóch świadków ${ }^{10}$. Prawodawca kościelny wychodzi z założenia, że decyzja o rezygnacji

\footnotetext{
${ }^{5}$ Por. KPK/83, kan. $189 \$ 1$.

${ }^{6}$ Por. M. LewickA, Rezygnacja, w: Encyklopedia katolicka, t. XVII, Lublin 2012, kol. 66.

${ }^{7}$ Por. KPK/83, kan. 187.

${ }^{8}$ Por. TAMże, kan. 188.

${ }^{9}$ Por. TAmże, kan. $149 \$ 3$.

${ }^{10}$ Por. TAmżE, kan. $189 \$ 1$.
} 
z urzędu jest na tyle ważna, zarówno dla wspólnoty parafialnej, jak też i dla samego zainteresowanego, że należy ją zabezpieczyć przed wszelkimi ułomnościami aktu ludzkiego. Jednocześnie tenże prawodawca zaleca władzy kościelnej, aby przyjmowała rezygnację popartą słuszną i proporcjonalną przyczyną ${ }^{11}$. Gdy chodzi o zrzeczenie się urzędu proboszcza słuszną przyczyną, oprócz poważnej i trwałej choroby, może być taki stan zdrowia, który nie pozwala na wykonywanie obowiązków w pełni efektywnie, powodując szkody duchowe dla wspólnoty parafialnej ${ }^{12}$. Decyzja ta może być dodatkowo uzasadniona specyfiką wymagań konkretnej parafii. Krytyczna ocena efektywności posługi pasterskiej, zwłaszcza w sytuacji wewnętrznych napięć czy nawet konfliktów we wspólnocie parafialnej jest także z całą pewnością wystarczającym motywem złożenia rezygnacji. W tym miejscu należy zwrócić uwagę, że prawodawca nie pozwala na samowolne porzucenie urzędu jak i na rezygnację wymuszoną czy wyłudzoną ${ }^{13}$.

Bardziej jasna sytuacja ma miejsce, gdy proboszcz składa rezygnację ze względu na osiągnięcie odpowiedniego wieku, który określa prawo powszechne lub partykularne ${ }^{14}$. Chodzi tu o wiek emerytalny. Prawodawca kodeksowy przyjmuje w całym Kościele jako wiek emerytalny dla proboszcza parafii osiągnięcie siedemdziesięciu pięciu lat $\dot{z ̇ y c i a}^{15}$. Zasadniczym motywem tej normy jest troska prawodawcy, aby

${ }^{11}$ Por. TAmże, kan. $189 \$ 2$.

${ }^{12}$ Ustawodawca przemyski stanowi, że gdy dobro duchowe parafii domaga się zmiany proboszcza wcześniej niż przewiduje prawo, proboszcz powinien oddać się do dyspozycji biskupa diecezjalnego, który przekaże odpowiedzialność za parafię innemu kapłanowi (por. Synod Archidiecezji Przemyskiej 1995-2000, st. $203 \$ 3$, Przemyśl 2000, s. 70).

${ }^{13}$ Por. J. SĄDEL, Kanoniczne powierzenie urzędu kościelnego w Kodeksach Prawa Kanonicznego z 1917 i 1983 r., Rzeszów 2008, s. 314-315.

${ }^{14}$ Por. KPK/83, kan. 185.

${ }^{15}$ Por. TAmżE, kan. 538 \$ 3. Już Sobór Watykański II w Dekrecie Christus Dominus (por. nr 31) zaapelował do proboszczów, aby z racji zaawansowanego wieku, sami dobrowolnie zrzekali się swego stanowiska. Prawodawca posoborowy, aby dostosować się do zalecenia Soboru wydał odpowiednie przepisy, w których zwrócił się do wszystkich proboszczów, aby bezpośrednio po przekroczeniu siedemdziesiątego piątego roku życia, sami dobrowolnie składali rezygnację ze swego urzędu na ręce 
urząd proboszcza, który wymaga odpowiedniej sprawności fizycznej i umysłowej, mógł być swobodnie sprawowany ku pożytkowi Ludu Bożego. Ukończenie określonego wieku nie stanowi automatycznie utraty urzędu, ale tworzy motyw, dla którego władza kościelna powinna rozważyć wszystkie okoliczności osoby i miejsca oraz podjąć decyzję o przyjęciu lub odłożeniu zrzeczenia. Należy też podkreślić, że rezygnacja wymaga przyjęcia przez tego, kto jest uprawniony do powierzenia urzędu, w tym przypadku biskup diecezjalny. Rezygnacja wymagająca przyjęcia traci moc, jeśli nie została przyjęta w ciągu trzech ciągłych miesięcy ${ }^{16}$. Osiąga skutek prawny z chwilą przyjęcia i doręczenia powiadomienia o jej przyjęciu ${ }^{17}$. Dopóki nie zostanie przyjęta, rezygnujący może odwołać rezygnację, nie może natomiast tego uczynić, gdy osiągnęła ona swój skutek. Utrata urzędu proboszcza w przypadku rezygnacji następuje $\mathrm{z}$ chwilą zaistnienia jej skutku. Tym samym urząd ten staje się urzędem wakującym.

Rezygnacji z powodu osiągnięcia określonego wieku dużo miejsca poświęcają również polskie statuty synodalne. Przyjmuje się w nich na ogół kodeksowy wiek siedemdziesięciu pięciu lat ${ }^{18}$, chociaż można zauważyć wyraźną tendencję do obniżania tej granicy często do lat siedemdziesięciu ${ }^{19}$ a nawet poniżej ${ }^{20}$. Należy zauważyć, że postanowie-

biskupa, który biorąc pod uwagę wszystkie okoliczności, zadecyduje o jej przyjęciu lub odroczeniu (por. PAwEe VI, Motu proprio Ecclesiae Sanctae, I, n. $20 \$ 3$ ).

${ }^{16}$ Por. KPK/83, kan. 189 § 3; R. SoBAŃsKi, Utrata urzędu..., s. 279.

${ }^{17}$ Por. TAмże, kan. 47.

${ }^{18}$ Por. Pierwszy Synod Diecezji Warszawsko-Praskiej, st. 71, Warszawa 2000, s. 64. Drugi Synod Częstochowski, st. 3.3.16, Częstochowa 1987, s. 194; I Synod Archidiecezji Białostockiej, st. 60 i 83, Białystok 2000, s. 30 i 36; Pierwszy Synod Diecezji Kaliskiej, st. 40, Kalisz 2009, s. 17; Pierwszy Synod Diecezji Toruńskiej, st. 190, Toruń 2011, s. 58; Aby byli jedno. Drugi Synod Diecezji Sandomierskiej, st. 93, Sandomierz 1999, s. 177.

${ }^{19}$ Por. I Synod Diecezji Łomżyńskiej, st. 166, Łomża 2005, s. 70; Synod Archidiecezji Przemyskiej, st. 203 \$2, s. 70; I Synod Diecezji Ełckiej, st. 353, Ełk 1999, s. 64.

${ }^{20}$ Por. Drugi Synod Częstochowski, st. 3.3.16, s. 195; Uchwały XLII Synodu Płockiego, st. 210, w: Miesięcznik Pasterski Płocki LXXXVI(1991) nr 10 bis, s. 42; IV Synod Diecezji Tarnowskiej, st. 347, Tarnów 1999, s. 182. Ustawodawca płocki i tarnowski zalecają proboszczom składanie rezygnacji po ukończeniu 65 lat, natomiast obowiązkowo muszą złożyć rezygnację po ukończeniu 75 roku życia. 
nia ustawodawców synodalnych w sprawie obniżenia wieku emerytalnego nie są formułowane $\mathrm{w}$ postaci nakazu prawnego, ale $\mathrm{w}$ formie zachęty lub zalecenia $\mathrm{z}$ uwzględnieniem uwarunkowań zdrowotnych lub innych ważnych powodów i potrzeb duszpasterskich ${ }^{21}$. Postanowienia te $z$ natury rzeczy, pod sankcją nieważności, nie mogą być sprzeczne $\mathrm{z}$ prawem powszechnym.

\section{Usunięcie}

\subsection{Postępowanie w sprawie usunięcia proboszcza}

Usunięcie to utrata urzędu wbrew woli osoby go zajmującej niepołączone $z$ nadaniem innego ${ }^{22}$. Przepisy określające sposób postępowania przy usuwaniu z urzędu kościelnego zostały zamieszczone w kan. 192-195. W procedurze usunięcia nie chodzi o pozbawienie urzędu, o którym traktuje w kan. 196, o czym będzie mowa poniżej, ani też o karne usunięcie proboszcza, które ma charakter pozbawienia urzędu, bowiem usunięcie niekoniecznie implikuje winę, chociaż w praktyce usunięcie z urzędu będzie odbierane jako dolegliwośćc ${ }^{3}$. W usunięciu nie chodzi o wymierzenie kary, lecz o dobro wspólne. Następuje ono albo mocą prawa albo dekretem kompetentnej wła$\mathrm{dzy}^{24}$. Z urzędu nadanego na czas nieokreślony, a także nadanego na czas określony, ale przed upływem tego czasu, może usunąć ten, komu przysługuje prawo nadania urzędu i w sytuacji zaistnienia poważnej przyczyny ${ }^{25}$, natomiast z urzędu nadanego na czas zależny

\footnotetext{
${ }^{21} \mathrm{~Np}$. po osiągnięciu wieku emerytalnego określonego w prawie cywilnym - 65 lat (por. Pierwszy Synod Diecezji Warszawsko-Praskiej, st. 138, s. 86). W diecezjach o licznym gronie prezbiterów, takim powodem może być zbyt długie oczekiwanie na urząd proboszcza.

${ }^{22}$ Por. Por. R. Sobański, Utrata urzędu..., s. 281.

${ }^{23}$ Por. E. Sztafrowski, Pozycja proboszcza w prawie kodeksowym, Prawo Kanoniczne 35(1992) nr 1-2, s. 64.

${ }^{24}$ Por. KPK/83, kan. 192.

${ }^{25}$ Taka poważna przyczyna zachodzi wtedy, gdy tytulariusz urzędu sprawuje go bezowocnie, czy też ze szkodą dla wspólnoty (por. np. kan. $253 \$ 3$ i kan. $810 \$ 1$ ).
} 
od nadającej władzy wystarcza słuszna przyczyna ${ }^{26}$ z zachowaniem sposobu postępowania określonego prawem. Prawo jednak nie przewiduje specjalnej procedury. Chodzi tu o zachowanie podstawowych wymogów sprawiedliwości, czyli przedstawienia przyczyny zamierzonego usunięcia, wysłuchanie zainteresowanego i jego racji oraz danie mu możliwości obrony ${ }^{27}$. Ponadto dekret usunięcia, aby osiągnął swój skutek musi być odpowiednio doręczony. Powinna też być w nim zamieszczona wzmianka o prawie wniesienia rekursu ${ }^{28}$. Prawodawca w przypadku usunięcia dekretem nakłada na kompetentną władzę obowiązek zabezpieczenia materialnego, przez odpowiedni czas, usuniętemu $z$ urzędu, gdy ten urząd stanowił podstawę jego utrzymania $^{29}$. Usunięcie zaś $\mathrm{z}$ urzędu mocą prawa nie wymaga żadnej interwencji organu administracyjnego i nie jest też karą kościelną, ale środkiem prawnym mającym na celu obronę dobra wspólnego, gdy tytulariusz urzędu znalazł się, w sposób zawiniony lub niezawiniony, w sytuacjach, niedających się pogodzić z zadaniami, jakie ma wykonywać sprawując urząd ${ }^{30}$. Do takich sytuacji prawodawca zaliczył utratę stanu duchownego ${ }^{31}$, publiczne odstąpienie od wiary katolickiej lub wspólnoty z Kościołem, lub w przypadku duchownego, który usiłował zawrzeć małżeństwo, choćby tylko cywilne ${ }^{32}$. Usunięcie następuje po zaistnieniu wyżej wymienionych faktów i ich pisemnym stwierdzeniu przez kompetentną władzę. Po stwierdzeniu należy zatroszczyć się o sanację czynności nieważnych i spowodować

\footnotetext{
${ }^{26}$ Por. KPK/83, kan. 193. Usunięcie z niektórych urzędów nie jest normowane postanowieniami tegoż kanonu (por. kan. 485; kan. $554 \S 3$; kan. 563; kan. 572 $\mathrm{i}$ inne).

${ }^{27}$ Por. R. Sobański, Utarta urzędu..., s. 282.

${ }^{28}$ Por. KPK/83. kan. 1732-1739. Rekurs taki wywiera skutek zawieszający, tzn. do czasu rozstrzygnięcia sprawy odwołujący się zachowuje urząd, ale nie wolno mu go wykonywać.

${ }^{29}$ Por. KPK/83, kan. 195.

${ }^{30}$ Por. R. SobAński, Utarta urzędu..., s. 283.

${ }^{31}$ Por. KPK/83, kan. 292. Szerzej na ten temat por. M. SтокŁosA, Utrata stanu duchownego w aktualnym ustawodawstwie Kościoła łacińskiego, Warszawa 2015.

${ }^{32}$ Por. KPK/83, kan. $194 \$ 1$.
} 
opuszczenie urzędu przez usuniętego, tak by urząd wakował faktycznie, a nie tylko prawnie ${ }^{33}$.

Oprócz zastosowania omówionych wyżej norm ogólnych dotyczących także usuwania proboszczów prawodawca kościelny przewidział jeszcze inny sposób postępowania, który posiada charakter procedury specjalnej określonej w kan. 1740-1747 ${ }^{34}$. Procedura przewidziana dla usuwania $\mathrm{z}$ urzędu proboszczów ma z pewnymi modyfikacjami również zastosowanie przy ich przenoszeniu. Prawodawca kodeksowy w tym przypadku określa jedną procedurę. Przy czym wydaje się, że procedura usuwania pod względem prawnym jest bardziej skomplikowana od procedury przenoszenia, bowiem zachodzi tutaj konieczność przedstawienia dokumentów i dowodów świadczących o szkodliwości lub nieskuteczności proboszczowskiego posługiwania. Tak, więc prawodawca stanowi, że w sytuacji, gdy posługiwanie proboszcza staje się szkodliwe lub przynajmniej nieskuteczne może on zostać usunięty przez biskupa diecezjalnego $\mathrm{z}$ parafii ${ }^{35}$. Kompetencje w tym względzie przysługują również tym wszystkim, którzy są w prawie zrównani $\mathrm{z}$ biskupem diecezjalnym ${ }^{36}$. W myśl tego postanowienia biskup może usunąć proboszcza z urzędu nawet wtedy, gdy owa szkodliwość lub nieskuteczność posługiwania nie wynika z poważnej winy, ale z jakiejś innej przyczyny. Jest to stwierdzenie dość ogólne, w którym mogą mieścić się różne postawy proboszcza. Wskazane przyczyny

\footnotetext{
${ }^{33}$ Por. R. SobAŃski, Utarta urzędu..., s. 284.

${ }^{34} \mathrm{~W}$ dawnym prawie kanonicznym prawodawca kościelny kierował się zasadą powiązania urzędu z beneficjum, stąd też wszyscy proboszczowie byli nieusuwalni. W procedurze administracyjnej usunięcia proboszcza określonej w Kodeksie z 1917 r. wprawdzie rozróżniano proboszczów nieusuwalnych od usuwalnych, ale swoboda biskupa względem obydwu rodzajów proboszczów była ograniczona, bowiem biskup mógł usunąć proboszcza wyłącznie w drodze procesowej i z przyczyn określonych w prawie (por. KPK/17, kan. 2147-2161).

${ }^{35}$ Por. KPK/83, kan. 1740.

${ }^{36}$ Por. TAmże, kan. $381 \$ 2$. Taką samą władzę posiada ordynariusz wojskowy (por. Jan PAweŁ II, Konstytucja apostolska Spirituali militum curae, VII). Należy też zauważyć, że tę władzę posiada administrator diecezjalny. Wikariusz generalny i biskupi mogą posiadać te kompetencje tylko na podstawie specjalnego mandatu biskupa diecezjalnego.
} 
zostały więc wymienione przykładowo nie zaś wyczerpująco, stąd praktycznie lista ich może być poszerzona, byleby mieściły się w ogólnym sformułowaniu przyjętym przez prawodawcę ${ }^{37}$. Szkodliwość lub nieskuteczność posługiwania proboszcza z natury swojej stanowią przyczynę podjęcia działania przez biskupa, ale należy zauważyć, że nie każde działanie proboszcza, choćby nie było wolne od błędów można uznać za szkodliwe. Chodzi tu o takie działanie, które wywołuje w odniesieniu do dobra wiernych rzeczywistą szkodę ${ }^{38}$. Przyczyną, bowiem działania biskupa nie jest ukaranie proboszcza, ale zapobieżenie szkodzie wynikającej z jego posługiwania ${ }^{39}$. Chodzi tu więc nie tylko o administracyjny wymiar posługi proboszcza, ale nade wszystko o wymiar duchowy, czyli o jego skuteczność oddziaływania duszpasterskiego.

Prawodawca kodeksowy oprócz tych ogólnych stwierdzeń określających przyczynę usunięcia proboszcza wymienia pięć możliwych przyczyn takiego szkodliwego lub nieskutecznego działania ${ }^{40}$. Pierwsza z nich dotyczy sposobu postępowania proboszcza, który przynosi kościelnej wspólnocie poważną szkodę lub zamieszanie ${ }^{41}$. Prawodawca nie precyzuje konkretnych przyczyn mogących spowodować taką

\footnotetext{
${ }^{37}$ Może chodzić tu o brak zarówno gorliwości pasterskiej, jak i przesadna gorliwość owocująca niekiedy rygoryzmem, wnoszącym do wspólnoty parafialnej wiele niepokoju. Może też chodzić o konflikty w parafii, które proboszcz swoim postępowaniem wywołał lub nawet o te, którym nie jest w stanie przeciwdziałać. Wydaje się, że nieporadność duszpasterska, która przynosi szkodę lub zamieszanie w parafii będzie wystarczającym powodem odwołania proboszcza. Przy czym w ocenie biskupa szkoda wywołana takimi postawami proboszcza musi być poważna.

${ }^{38}$ Por. G. Leszczyński, Kościelna procedura administracyjna w Kodeksie Prawa Kanonicznego Jana Pawła II, Warszawa 2008, s. 173.

${ }^{39}$ Por. Z. Grocholewski, Transferimento e remozione del parroco, w: La parrocchia, Città del Vaticano 1997, s. 217.

${ }^{40}$ Por. KPK/83, kan. 1741. Prawodawca poprzedniego Kodeksu również wymieniał pięć takich przyczyn. Różnią się one jednak nieznacznie w swej treści (trzy są identyczne, a dwie są nowe).

${ }^{41}$ Por. KPK/83, kan. 1741, 1º.
} 
sytuację $^{42}$, zaznacza jedynie, że szkoda ma być poważna. Należy sądzić, że ocena zaistniałej sytuacji należy do biskupa diecezjalnego. Drugą przyczyną jest nieudolność lub trwała choroba fizyczna lub umysłowa, która czyni proboszcza nieużytecznym w wypełnianiu zadań ${ }^{43}$. Prawodawca nie ma tu na względzie nieudolności czy choroby jako takiej, ale stany na tyle obciążające, że powodują nieużyteczność w działaniu. W myśl postanowienia chodzi tu o trzy sytuacje: nieudolność, trwałą chorobę umysłową lub fizyczną. Nieudolność może być wynikiem braku wiedzy, roztropności czy też braku umiejętności głoszenia kazań lub organizowania katechezy ${ }^{44}$. Z kolei choroba umysłowa oznacza jakąkolwiek chorobę psychiczną ${ }^{45}$, zaś choroba fizyczna to jakakolwiek choroba natury cielesnej ${ }^{46}$. W przypadku chorób pewną trudnością będzie określenie momentu, od którego proboszcz jest nieużyteczny w posługiwaniu. W ocenie sytuacji biskup powinien zasięgnąć opinii biegłego lekarza. Ponadto biskup ma ocenić stopień niezdolności proboszcza do spełniania swoich zadań w stosunku do potrzeb danej parafii oraz rozważyć, czy nie można zaradzić sytuacji w inny sposób, np. dokonując podziału obowiązków pomiędzy wikariuszy ${ }^{47}$. Trzecia przyczyna dotyczy dwóch różnych kwestii, mianowicie utraty dobrego imienia u uczciwych i poważnych parafian oraz niechęci w stosunku do proboszcza, które według przewidywania szybko nie ustaną ${ }^{48}$. Wynika z tego, że utrata dobrego imienia i niechęć chwilowa spowodowana jakimś szczególnym wydarzeniem nie może być powodem wszczęcia postępowania zmierzającego do usunięcia. Przyczyny utraty dobrego imienia i niechęci mogą

\footnotetext{
${ }^{42}$ Może to być np. gorszący lub znacznie odbiegający od ogólnie przyjętych norm styl życia proboszcza.

${ }^{43}$ Por. KPK/83, kan. 1741, 2º.

${ }^{44}$ Por. J. Krukowski, Prawo administracyjne w Kościele, Warszawa 2011, s. 411.

${ }^{45}$ Może to być np. schizofrenia, mitomania.

${ }^{46} \mathrm{~Np}$. utrata słuchu, mowy, paraliż.

${ }^{47}$ Por. J. KRukowski, Prawo administracyjne..., s. 412.

${ }^{48}$ Por. KPK/83. kan. 1741, $3^{\circ}$.
} 
być różne ${ }^{49}$, a prawodawca nie precyzuje źródła ich pochodzenia. Chodzi tu jednak o taką sytuację, która utrudnia duszpasterzowanie. Zadaniem biskupa diecezjalnego będzie dokonanie rzetelnego osądu i stwierdzenie, czy utrata dobrego imienia lub niechęć parafian jest konsekwencją postępowania proboszcza, a więc zaistniałych faktów $\mathrm{z}$ jego życia, czy też innych nieobiektywnych racji ${ }^{50}$. Czwartą przyczynę stanowią poważne zaniedbania lub naruszenia obowiązków parafialnych, które trwają pomimo upomnienia ${ }^{51}$. Jak wynika z postanowienia kanonu biskup może wszcząć procedurę usunięcia po wcześniejszym bezskutecznym upomnieniu proboszcza. Piątą przyczyną jest złe zarządzanie dobrami doczesnymi $\mathrm{z}$ wielką szkodą dla Kościoła, ilekroć nie można temu zaradzić w inny sposób ${ }^{52}$. Oznacza to, że biskup nie powinien wszczynać procedury usunięcia $\mathrm{z}$ wyżej wymienionej przyczyny, jeśli można inaczej zaradzić sytuacji np. biskup może upoważnić wikariusza do administrowania majątkiem kościelnym albo upomnieć proboszcza wskazując na konieczność podjęcia konkretnych działań naprawczych ${ }^{53}$.

Powyższe przyczyny, wskazane w cytowanym kanonie, $\mathrm{z}$ woli prawodawcy nie są wyliczone taksatywnie, a jedynie przykładowo. Tak, więc podstawę do wszczęcia procedury usunięcia mogą stanowić jeszcze inne przyczyny o ile działanie proboszcza staje się szkodliwe lub nieskuteczne $e^{54}$.

\footnotetext{
${ }^{49}$ Taką przyczyną może być np. rażąca chciwość proboszcza, wykrycie jego dawnego przestępstwa, które ze względu na przedawnienie jest niekaralne albo jego lekkomyślny tryb życia (por. T. PAwluk, Prawo kanoniczne według Kodeksu Jana Pawła II, t. IV, Olsztyn 1990, s. 396).

${ }^{50}$ Por. G. Leszczyński, Kościelna procedura administracyjna..., s. 177.

${ }^{51}$ Por. KPK/83. kan. 1741, 4. Może taka sytuacja wynikać z bezprawnego przebywania proboszcza poza parafią albo z zaniedbań w prowadzeniu katechizacji, w głoszeniu homilii w niedzielę i święta nakazane, czy też w sprawowaniu sakramentów (por. T. PAwluk, Prawo kanoniczne..., t. IV, s. 396).

${ }^{52}$ Por. KPK/83. kan. $1741,5^{\circ}$.

${ }^{53}$ Por. J. Krukowski, Prawo administracyjne..., s. 413.

${ }^{54}$ Taką przyczyną może być niedyspozycyjność proboszcza, który nie złożył rezygnacji po ukończeniu siedemdziesiątego piątego roku życia albo niepotrzebne zaangażowanie się proboszcza w działalność pozaduszpasterską albo też rażący
} 
Procedura usunięcia zawiera kilka istotnych etapów: dochodzenie wstępne, wezwanie proboszcza do złożenia dymisji, jego odpowiedź na wezwanie, dekret usunięcia wydany przez biskupa diecezjalnego. Dochodzenie wstępne rozpoczyna się, gdy biskup diecezjalny na podstawie przeprowadzonego badania stwierdzi, że istnieje obiektywna i realna przyczyna określona prawnie, powodująca, że posługiwanie proboszcza jest szkodliwe lub przynajmniej nieskuteczne. Następnie tenże biskup powinien zasięgnąć opinii dwóch proboszczów, będących członkami specjalnego stałego zespołu wskazanego w tym celu przez radę kapłańską na jego wniosek ${ }^{55}$. W skład takiego zespołu mogą wchodzić członkowie rady kapłańskiej, jak i proboszczowie spoza rady. Ich liczbę określa biskup diecezjalny, tak, aby w razie jakiejś przeszkody któregoś z proboszczów można było taką konsultację przeprowadzić. Jest ona, bowiem wymagana przez prawo, a więc jest warunkiem legalności całej procedury ${ }^{56}$. Należy zauważyć, że prawodawca kodeksowy nie precyzuje kwestii, czy biskup powinien konsultować każdego z proboszczów oddzielnie, czy też razem i nie określa czasu konsultacji. Proboszczowie mogą swoją opinię wyrazić na piśmie lub przekazać ją ustnie. Każdy z nich jednak ma wyrazić swoją opinię szczerze, a także zachować konieczną tajemnicę chyba, że biskup zdecyduje inaczej ${ }^{57}$. Biskup nie jest jednak związany opinią proboszczów. Może więc działać zgodnie ze swoją oceną, tzn. ani ich opinia negatywna, ani pozytywna nie wiąże biskupa ${ }^{58}$. Gdyby biskup diecezjalny po przeprowadzonej konsultacji doszedł do przekonania, że należy przystąpić do dalszego działania powinien skierować do

brak kultury (por. T. Pawluk, Prawo kanoniczne..., t. IV, s. 397) albo też niegodny, gorszący sposób postępowania, trwała choroba, alkoholizm, utrata dobrego imienia, poważne zaniedbywanie obowiązków parafialnych, nadużycia w gospodarowaniu dobrami parafialnymi (por. I Synod Diecezji Łomżyńskiej, st. 165, s. 70).

${ }^{55}$ Por. KPK/83, kan. $1742 \$ 1$.

${ }^{56}$ Por. J. Krukowski, Procedura przy usuwaniu lub przenoszeniu proboszczów, w: Komentarz do Kodeksu Prawa Kanonicznego, t. V, red. J. Krakowski, Pallottinum 2007, s. 440.

${ }^{57}$ Por. KPK/83, kan. $127 \$ 3$.

${ }^{58}$ Por. TAMżE, kan. $127 \$ 2,2^{\circ}$. 
proboszcza, po przedstawieniu mu przyczyn i argumentów, ojcowskie wezwanie, aby w ciągu piętnastu dni złożył rezygnację z urzędu ${ }^{59}$. Przedstawienie przyczyn i argumentów jest wyraźnie wymagane do ważności procedury i ma służyć zabezpieczeniu należnego proboszczowi prawa do obrony. Wezwanie, aby mogło być udowodnione na forum zewnętrznym, powinno być sporządzone na piśmie, a jeżeli ustnie to w obecności notariusza lub dwóch świadków ${ }^{60}$. Omawiana procedura nie dotyczy proboszczów będących członkami instytutu zakonnego lub stowarzyszenia życia apostolskiego, którzy mogą być usuwani według uznania biskupa diecezjalnego lub własnego przełożonego wyższego ${ }^{61}$.

Proboszcz w odpowiedzi na wezwanie do rezygnacji może zrezygnować $z$ urzędu ${ }^{62}$, albo nie odpowiedzieć biskupowi, albo też podważyć jego argumenty, podejmując obronę. Jeśli więc proboszcz rezygnuje z urzędu powinien to uczynić na piśmie, lub w obecności dwóch świadków ${ }^{63}$ i wówczas procedura osiąga swój skutek. Rezygnacja jest nieodwołalna i nie wymaga akceptacji biskupa, ponieważ nastąpiła po wezwaniu biskupa. Rezygnacja może być też złożona pod warunkiem, który jednak nie może być sprzeczny z ogólnymi zasadami prawa i dyscypliny kościelnej. Wówczas wymaga faktycznego zaakceptowania przez biskupa w ciągu trzech miesięcy ${ }^{64}$. W tym czasie proboszcz może odstąpić od rezygnacji. Rezygnacja traci moc,

\footnotetext{
${ }^{59}$ Por. TAmże, kan. $1742 \S 1$.

${ }^{60}$ Por. J. Krukowski, Procedura przy usuwaniu..., s. 441.

${ }^{61}$ Por. KPK/83, kan. $682 \$ 2$. Brak wymogu zaistnienia przyczyn usunięcia, określonych w prawie i przewidzianej procedury powodowany jest obowiązkiem posłuszeństwa zakonnika wynikającym ze ślubu. Podobnie też w sytuacji, gdzie przyczyną usunięcia proboszcza jest choroba umysłowa, nie ma miejsca wezwanie do rezygnacji, ale biskup na podstawie pewnych dokumentów może przystąpić do wydania dekretu usunięcia (por. L. Chiapetta, Il Codice di Diritto Canonico. Commento giuridico-pastorale, Napoli, s. 796).

${ }^{62}$ Por. KPK/83, kan. 1743.

${ }^{63}$ Por. KPK/83, kan. $189 \$ 1$. Rezygnacja dokonana pod wpływem ciężkiej i niesprawiedliwej bojaźni, podstępu, błędu istotnego lub symonii jest nieważna (kan. 188).

${ }^{64}$ Por. KPK/83, kan. $189 \$ 3$.
} 
jeśli nie zostanie zaakceptowana przez biskupa, po akceptacji osiąga swój skutek i nie może być odwołana przez zrzekającego się ${ }^{65}$.

Jeśli natomiast proboszcz nie odpowie w ciągu piętnastu dni biskup ponawia wezwanie przedłużając czas użyteczny na odpowied $z^{66}$. Należy zauważyć, że prawodawca nie określił czasu odpowiedzi i pozostawił jego wyznaczenie biskupowi. Ten drugi termin powinien być wystarczający na to, aby proboszcz miał czas na ostateczną refleksję i odpowiedź ${ }^{67}$. Jeśli proboszcz ponownie wezwany nie odpowie w określonym czasie mimo braku jakiejkolwiek przyczyny lub odmawia złożenia rezygnacji bez podania jakichkolwiek motywów, biskup po ponownym zbadaniu sytuacji ${ }^{68}$ winien wydać dekret usunięcia proboszcza ${ }^{69}$.

Jeśli zaś proboszcz wezwany do rezygnacji podważa argumenty biskupa dotyczące jego usunięcia, korzystając z prawa do obrony, wówczas biskup powinien ocenić czy przedstawione przez proboszcza motywy są wystarczające, aby odstąpić od procedury ${ }^{70}$. W sytuacji, gdy biskup uzna przedstawione przez proboszcza środki dowodowe, dokumenty, opinie świadków może zaniechać usunięcia. Jeżeli jednak biskup po zapoznaniu się ze środkami dowodowymi uzna je za niewystarczające to do ważności swego działania winien wezwać proboszcza, aby ponownie przejrzał swoje argumenty, środki dowodowe i w pisemnej relacji przedstawił swój sprzeciw, nawet przeciwne dowody, jeśli takie posiada ${ }^{71}$. Następnie po uzupełnieniu postępowania dowodowego biskup powinien sprawę rozważyć z dwoma tymi

\footnotetext{
${ }^{65}$ Por. TAmże, kan. $189 \$ 4$.

${ }^{66}$ Por. TAmże, kan. $1744 \$ 1$.

${ }^{67}$ Por. J. Krukowski, Procedura przy usuwaniu..., s. 442.

${ }^{68}$ Biskup przed wydaniem dekretu winien mieć pewność, że proboszcz otrzymał ponowne wezwanie i obiektywne okoliczności nie wykluczają możliwości odpowiedzi proboszcza.

${ }^{69}$ Por. KPK/83, kan. $1744 \$ 2$.

${ }^{70}$ Por. TAmże, kan. 1745.

${ }^{71}$ Por. TAmże, kan. 1745, 10. Wydaje się, że należy tu zastosować analogię do pierwszego wezwania i przyjąć piętnastodniowy termin odpowiedzi proboszcza (por. J. KRukowski, Prawo administracyjne..., s. 416).
} 
samymi proboszczami, o których była wyżej mowa, chyba, że trzeba wyznaczyć innych, bo ci sami z jakichś ważnych powodów nie mogą być wezwani ${ }^{72}$. Wówczas po zasięgnięciu opinii proboszczów biskup powinien osobiście podjąć decyzję dotyczącą usunięcia proboszcza $\mathrm{z}$ urzędu lub pozostawienia go parafii i w tej sprawie wydać dekret ${ }^{73}$, który powinien być wydany na piśmie i spełniać wszystkie wymogi prawa $^{74}$. Dekret usuwający proboszcza powinien ponadto zawierać motywy usunięcia ${ }^{75}$ oraz zagwarantowaną możliwość wniesienia rekursu od decyzji biskupa. Także wtedy, gdy biskup podejmuje decyzję o nie usuwaniu proboszcza powinien być wydany dekret, ale już bez podawania motywacji ${ }^{76}$. Niezależnie od treści dekretu powinien on być doręczony jako prawomocny dokument ${ }^{77}$. Dekret może być przesłany pocztą za poświadczeniem odbioru lub doręczony przez osobę wyznaczona przez biskupa ${ }^{78}$. W przypadku zaistnienia poważnej przyczyny uniemożliwiającej doręczenie dekretu powiadomienie o dekrecie dokonuje się poprzez jego odczytanie usuniętemu proboszczowi w obecności notariusza lub dwóch świadków ${ }^{79}$. Podobnie, jeśli proboszcz bez słusznego powodu nie odebrał dekretu albo odmówił złożenia podpisu po jego odczytaniu dekret uważa się za doręczony zgodnie $z$ prawem ${ }^{80}$.

\subsection{Skutki usunięcia proboszcza}

Biskup diecezjalny usuniętemu proboszczowi powinien powierzyć inny urząd lub wyznaczyć pensję zależnie od potrzeby i stosownie do okoliczności ${ }^{81}$. Jeśli jednak przyczyny usunięcia były zawinione i dalej

\footnotetext{
${ }^{72}$ Por. KPK/83, kan. $1745,2^{\circ}$.

${ }^{73}$ Por. TAmże, kan. $1745,3^{\circ}$.

${ }^{74}$ Por. TAmże, kan, 37, 51, $193 \$ 4$.

${ }^{75}$ Por. T. PAwluk, Prawo kanoniczne..., t. IV, s. 398.

${ }^{76}$ Por. L. Chiapetta, Il Codice di Diritto Canonico..., s. 798

${ }^{77}$ Por. KPK/83, kan. $54 \$ 2$.

${ }^{78}$ Por. G. Leszczy Ński, Kościelna procedura administracyjna..., s. 184.

${ }^{79}$ Por. TAmże, kan. 55.

${ }^{80}$ Por. TAMżE, kan. 56.

${ }^{81}$ Por. TAmże, kan 1746.
} 
uniemożliwiają właściwe spełnianie przez niego urzędów kościelnych biskup nie powinien powierzać mu nowego urzędu. W sytuacji zaś, gdy przyczyny usunięcia nie były przez proboszcza zawinione, wówczas zapewnienie mu odpowiedniego utrzymania jest bezspornym obowiązkiem biskupa $^{82}$. Także względy humanitarne mogą domagać się uregulowania tej sprawy. Biskup nie jest jednak przynaglony do zapewnienia usuniętemu proboszczowi pełnego utrzymania, jeśli z okoliczności wynika, że jest to zbyteczne lub niewskazane ${ }^{83}$. Ponadto usunięcie proboszcza powoduje określone w prawie skutki dotyczące jego osoby. Powinien on przede wszystkim powstrzymać się od wykonywania zadań proboszczowskich. Dekret biskupa pozbawia go urzędu, a tym samym władzy oraz praw i obowiązków z nim związanych. Usunięty proboszcz powinien też opuścić dom parafialny, chyba że w przypadku choroby nie mogąc przenieść się na inne miejsce otrzyma od biskupa pozwolenie na pozostanie w nim. Powinien też przekazać wszystko, co należy do parafii temu, komu biskup parafię powierzył ${ }^{84}$.

Usunięty proboszcz może złożyć w ciągu dziesięciu dni użytecznych prośbę do biskupa o odwołanie dekretu ${ }^{85}$. Ma też prawo wniesienia rekursu do Kongregacji Duchowieństwa ${ }^{86}$, której rozstrzygnięcie może być zaskarżone do Drugiej Sekcji Sygnatury Apostolskiej, czy to przez usuniętego proboszcza, czy przez biskupa ${ }^{87}$. Wniesienie rekursu, aż do czasu rozstrzygnięcia sprawy ma skutek zawieszający. Dlatego w przypadku wniesienia rekursu przez usuniętego proboszcza

\footnotetext{
${ }^{82}$ Por. TAmże, kan. 195 i 281.

${ }^{83}$ Por. T. Pawluk, Prawo kanoniczne..., t. IV, s. 399.

${ }^{84}$ Por. KPK/83, kan. $1747 \$ 1$ i 2.

${ }^{85}$ Por. TAmże, kan. 1734.

${ }^{86}$ Por. Jan PaweŁ II, Konstytucja apostolska Pastor Bonus, art. 93, w: Ustrój hierarchiczny kościoła. Wybór Źródeł, red. W. Kacprzyk, M. Sitarz, Lublin 2006, s. 217-257.

${ }^{87}$ Por. KPK/83, kan. $1445 \$ 2$ także Benedictus XVI, Motu proprio Antiqua ordinatione, art. 104, AAS 100(2008) 513-538. Szerzej na ten temat por. G. LESzCZYŃsKi, Procedura rekursu do II Sekcji Sygnatury Apostolskiej, Prawo Kanoniczne 57(2014) nr 2, s. 71-90.
} 
biskup nie może powierzyć parafii nowemu proboszczowi, wówczas ustanawia administratora parafialnego ${ }^{88}$, który wypełnia obowiązki proboszcza. Stąd też czysto teoretyczne znaczenie mają rozbieżne opinie autorów w kwestii czy parafia po dekrecie usunięcia proboszcza, a w czasie trwania rekursu wakuje czy też nie ${ }^{89}$.

Należy podkreślić, że jeśli chodzi o specjalną procedurę usuwania proboszczów polskie ustawy synodalne nie wnoszą konkretnych uzupełnień, bowiem są to procedury ściśle określone prawem, a od ich dokładnego stosowania zależy niekiedy ważność podejmowanej przez biskupa diecezjalnego decyzji administracyjnej.

\section{Przeniesienie}

\subsection{Postępowanie w sprawie przeniesienia proboszcza}

Dla zapewnienia możliwości dobierania odpowiednio przygotowanych osób do pełnienia urzędów w Kościele prawodawca kodeksowy w kan. 190-191 określił instytucję przeniesienia na inny urząd. Przeniesienie zatem to akt prawny mocą, którego kompetentna władza zwalnia kogoś z urzędu, nadając mu jednocześnie inny ${ }^{90}$, albo inaczej to utrata jednego urzędu i nabycie innego. Przeniesienie może być karne ${ }^{91}$ i jest przewidziane wśród kar ekspiacyjnych lub administracyjne na mocy dekretu kompetentnej władzy. W pierwszym przypadku dokonuje się ono zgodnie z procedurą przewidzianą

\footnotetext{
${ }^{88}$ Por. KPK/83, kan. $1747 \$ 3$.

${ }^{89}$ Por. T. Pieronek, Administracyjne usunięcie lub przeniesienie proboszcza, Prawo Kanoniczne 32(1989) nr 1-2, s. 38.

${ }^{90}$ Por. T. PAwluk, Prawo kanoniczne według Kodeksu Jana Pawła II, t. I, Olsztyn 1985, s. 311; Szerzej na ten temat por. G. DzIERżon, Przeniesienie z urzędu kościelnego (kan. 190-191), Seminare 26(2009), s. 159-170.

${ }^{91}$ Por. KPK/83, kan. $1336 \$ 1,4^{\circ}$. Prawodawca kodeksowy nie wymienia przestępstwa, za które przewiduje sankcję karnego przeniesienia na inny urząd, stąd też karne przeniesienie może mieć miejsce za przestępstwo sankcjonowane karą nieokreśloną.
} 
$\mathrm{w}$ prawie ${ }^{92}$, w drugim zaś zgodnie z prawem. Przeniesienie może być zgodne z wolą przenoszonego czy też na zasadzie porozumienia albo dokonane wbrew jego woli ${ }^{93}$. W pierwszym przypadku powinna go poprzedzać rezygnacja z zajmowanego stanowiska i wystarcza jakakolwiek słuszna przyczyna w drugim zaś, gdy dokonuje się wbrew woli przenoszonego, musi istnieć poważna przyczyna z zachowaniem sposobu postępowania przewidzianego prawem ${ }^{94}$. Przyczyna przeniesienia musi być podana do wiadomości przenoszonemu, ponieważ ma on prawo przedstawienia swoich racji przeciwnych. Ponadto po wydaniu dekretu przysługuje mu prawo rekursu ze skutkiem zawieszającym. Przeniesienie osiąga swój skutek wraz z kanonicznym objęciem nowego urzędu i powoduje wakat urzędu pierwszego, chyba że co innego przewiduje prawo lub zarządzi kompetentna władza ${ }^{95}$.

Podobnie jak przy usuwaniu proboszczów także dla ich przenoszenia została określona specjalna procedura administracyjna. Tak, więc przy przenoszeniu proboszczów na inną parafię lub inny urząd prawodawca, ze względu na doniosłą rolę, jaką proboszczowie spełniają w życiu wspólnoty kościelnej oraz na fakt stałości ich urzędu, przewiduje taką właśnie procedurę ${ }^{96}$. Ta szczególna rola proboszcza, który jest własnym pasterzem zleconej mu wspólnoty kościelnej (parafii) ukierunkowana jest na potrzeby duchowe wiernych i wymaga od niego pełnego zaangażowania oraz troski o funkcjonowanie owej wspólnoty. Przewidziana procedura ma zatem na celu eliminowanie sytuacji, w których okoliczności nawet niezawinione ze strony proboszcza mogłyby pozbawić wiernych dóbr duchowych, do których

\footnotetext{
${ }^{92}$ Por. KPK/83, kan. 1717-1728. Chodzi to o przeniesienie w drodze procesu karnego.

${ }^{93}$ Por. KPK/83, kan. $190 \$ 2$.

${ }^{94}$ Wymóg ten nie dotyczy przenosin w ramach instytutów życia konsekrowanego i stowarzyszeń życia apostolskiego, także tych zakonników, którzy spełniają jakieś posługi dla dobra diecezji (por. KPK/83, kan. $682 \$ 2$ ).

${ }^{95}$ Por. KPK/83, kan. $191 \$ 1$. Przenoszony pobiera wynagrodzenie związane z pierwszym urzędem do czasu kanonicznego objęcia drugiego (por. \$2).

${ }^{96}$ Por. TAмżE, kan. 1748-1752.
} 
mają prawo ${ }^{97}$ i zmierza do poszukiwania większego dobra. Stąd procedura, jaką prawodawca przewiduje w tej sytuacji ma na celu z jednej strony dobro duchowe wiernych, z drugiej zaś strony gwarantuje obiektywne spojrzenie na posługę proboszcza.

Omawiając, więc kwestie dotyczące przenoszenia proboszczów należy odróżnić procedurę administracyjną na mocy dekretu wydanego przez kompetentną władzę i o takiej będzie mowa, od karnej procedury przeniesienia na inny urząd, o której prawodawca traktuje w innym miejscu. W Kodeksie Jana Pawła II przewidziana jest jedna procedura przenoszenia proboszczów ${ }^{98}$. Powstaje jednak pytanie, kogo owa procedura dotyczy, bowiem prawodawca wymienia różne kategorie proboszczów, tzn. czy podmiotem postępowania jest każdy proboszcz, czy też prawo przewiduje jakieś wyjątki. W odpowiedzi na tak postawione pytanie należy podkreślić, że procedura przeniesienia dotyczy tych wszystkich, którzy są własnymi pasterzami parafii erygowanych na stałe ${ }^{99}$, jak również tych, którzy spełniają obowiązki proboszczowskie w parafiach tymczasowych ${ }^{100}$. Procedurze tej podlega, zatem każdy proboszcz niezależnie od charakteru stałości swojego urzędu, bowiem stałość proboszcza nie jest związana z urzędem, ale z jego statusem, a także niezależnie od wieku. Stałością cieszą się proboszczowie parafii terytorialnych, jak i parafii personalnych, a także parafii powierzonych solidarnie kilku kapłanom, kapelani wojskowi pełniący funkcję proboszcza oraz kapelani misji sui iuris ${ }^{101}$.

\footnotetext{
${ }^{97}$ Por. TAmże, kan. 213 nn.

${ }^{98}$ Przede wszystkim z tej racji, że Sobór Watykański II zniósł instytucję proboszcza nieusuwalnego (por. Dekret Christus Dominus, nr 31). W Kodeksie z 1917 r. przenoszenie proboszczów nieusuwalnych było zastrzeżone Stolicy Apostolskiej, zaś proboszczów usuwalnych mógł przenosić biskup diecezji, ale jeśli była to parafia gorsza od tej, którą dany proboszcz aktualnie zajmował, wymagana była zgoda również Stolicy Apostolskiej (por. KPK/1917, kan. 2162-2167).

${ }^{99}$ Por. KPK/83, kan. 519.

${ }^{100}$ Por. TAmżE, kan. $516 \$ 1$.

${ }^{101}$ Por. G. Leszczý́ski, Kościelna procedura administracyjna $w$ Kodeksie Prawa Kanonicznego Jana Pawła II, Warszawa 208, s. 160-161.
} 
Prawodawca kodeksowy stanowi, że motywem przeniesienia proboszcza może być albo dobro dusz albo potrzeba lub pożytek Kościoła $^{102}$. Należy zauważyć, że przyczyny przeniesienia proboszcza różnią się od tych, które skłaniają biskupa do podjęcia procedury usunięcia go $\mathrm{z}$ urzędu ${ }^{103}$. Przy przeniesieniu uwaga prawodawcy skupia się wokół innych okoliczności niż przy usunięciu, nie mają one charakteru szkodliwego działania ani negatywnej oceny osoby proboszcza ${ }^{104}$. Proboszcz, który ma być przeniesiony może owocnie pracować w parafii, jednak motywy wyżej wskazane mogą skłonić biskupa diecezjalnego do wszczęcia procedury przeniesienia. Biskup mając na względzie inną parafię lub urząd w kontekście dobra dusz lub potrzeby i pożytku Kościoła może więc dokonać przeniesienia. Chociaż procedura przeniesienia i usunięcia zawierają elementy wspólne to jednak biskup nie powinien stosować procedury przeniesienia proboszcza opierając się na przesłankach, które mogą wyłącznie stanowić podstawę usunięcia go z urzędu. Motywy przeniesienia proboszcza, na które wskazuje prawodawca nie zawsze muszą skłaniać biskupa do przeniesienia na większą lub bardziej znaczącą parafię lub wyższy urząd. Dobro dusz albo potrzeba lub pożytek Kościoła mogą uzasadniać przeniesienie na mniejszą parafię lub niższy urząd. Należy dodać, że biskup może dokonać przeniesienia proboszcza jedynie na parafię wakującą lub wakujący urząd.

Władzą kompetentną do dokonania procedury przeniesienia jest biskup diecezjalny. Pod pojęciem biskupa diecezjalnego należy rozumieć również tych wszystkich, którzy na mocy prawa są z nim zrównani ${ }^{105}$. Ponadto władzę tę, o ile nie przewidziano inaczej w prawie

\footnotetext{
${ }^{102}$ Por. KPK/83, kan. 1748. W nowym Kodeksie nastąpiło poszerzenie motywów przeniesienia proboszcza, bowiem w Kodeksie z 1917 r. motywem przeniesienia proboszcza było wyłącznie dobro dusz (KPK/17, kan. 2162). Ma to związek z faktem, że poprzedni Kodeks przewidywał jedynie przeniesienie na inną parafię, zaś zgodnie z postanowieniem obecnego Kodeksu przewidziane jest przeniesienie proboszcza także na inny urząd.

${ }^{103}$ Por. KPK/83, kan. 1741.

${ }^{104}$ Por. T. Pieronek, Administracyjne usunięcie..., s. 39.

${ }^{105}$ Por. KPK/83, kan. $381 \S 2$.
} 
partykularnym, posiada ordynariusz wojskowy i przełożony misji sui iuris, a także administrator diecezjalny, ponieważ prawo mu jej nie wyklucza ${ }^{106}$. Natomiast kompetencje te nie przysługują wikariuszowi generalnemu i wikariuszowi biskupiemu chyba, że otrzymali specjalny mandat od biskupa diecezjalnego.

Prawodawca kodeksowy wskazuje kilka etapów w procedurze przeniesienia, m.in. propozycja przeniesienia, odpowiedź proboszcza, ewentualne ponowne wezwanie biskupa i dekret o przeniesieniu. $\mathrm{W}$ procedurze przeniesienia nie ma wstępnego postępowania, ponieważ jej przyczyną nie jest ocena postępowania proboszcza, ale dobro dusz lub pożytek Kościoła. Biskup diecezjalny dostrzegając to dobro kieruje na piśmie do proboszcza propozycję ${ }^{107}$, w której podkreśla ten właśnie motyw i wskazuje nową parafię lub nowy urząd, który ma zamiar powierzyć zachęcając, aby propozycję przyjął. Chodzi tutaj o odwołanie się do kryteriów wyższych niż dobro proboszcza. Poszukiwanie większego dobra dusz lub pożytku Kościoła jest, bowiem celem nadrzędnym każdej działalności kościelnej. Ta motywacja jest szczególnie istotna w sytuacji, gdy przeniesienie pociąga za sobą konieczność poniesienia przez proboszcza jakichś ofiar ze względu na trudniejsze warunki ${ }^{108}$. W sytuacji, gdy proboszcz propozycję przeniesienia przyjmie biskup powinien wydać dekret przeniesienia. Dekret wydany zgodnie z prawem kończy procedurę przeniesienia.

W sytuacji natomiast, w której proboszcz nie przyjmuje propozycji biskupa i nie zgadza się na przeniesienie powinien przedstawić na piśmie swoje racje ${ }^{109}$. Prawodawca nie wskazuje terminu, w którym proboszcz powinien owe racje przedstawić biskupowi, ale wydaje się, że skoro motywem przeniesienia jest dobro dusz termin ten powinien być niedługi. Gdyby proboszcz unikał odpowiedzi biskup może mu określić czas na odpowiedźn ${ }^{110}$. W przypadku, gdyby biskup uważał,

\footnotetext{
${ }^{106}$ Por. TAmże, kan. $427 \$ 1 \mathrm{w}$ kontekście kan. 525, 2º.

${ }^{107}$ Por. TAmże, kan. 1748.

${ }^{108}$ Por. J. KRukowski, Prawo administracyjne...e, s. 421.

${ }^{109}$ Por. KPK/83, kan. 1749.

${ }^{110}$ Por. G. Leszczyński, Kościelna procedura administracyjna..., s. 191.
} 
że racje przedstawione przez proboszcza nie są przekonywujące i nie należy odstępować od propozycji przeniesienia, powinien rozważyć sprawę z dwoma proboszczami konsultorami powołanymi na stałe do tego celu spośród kandydatów zgłoszonych przez radę kapłańską ${ }^{111}$. Dyskusja powinna dotyczyć oceny racji przemawiających za przeniesieniem jak i przeciw przeniesieniu zgłoszonych przez proboszcza. Opinie proboszczów konsultorów mogą być przychylne dla proboszcza lub zgodne z propozycją biskupa ${ }^{112}$. Konsultacja, której dokonuje biskup jest wymagana do ważności procedury, nie jest on jednak skrępowany opinią proboszczów i gdyby nadal uważał, że nie należy odstępować od propozycji przeniesienia powinien ponowić wobec proboszcza ojcowskie wezwanie. Chociaż prawodawca wyraźnie nie stawia wymogu pisemnego wezwania, to jednak wydaje się, że powinno być ono sporządzone na piśmie, aby mogło rodzić skutki prawne. Ponadto w piśmie tym powinna być zamieszczona informacja o przeprowadzonej dyskusji z proboszczami konsultorami. W sytuacji, jeśli proboszcz nadal nie chce przyjąć propozycji przeniesienia, a biskup uważa, że przeniesienie jest konieczne, prawodawca upoważnia biskupa do wydania dekretu przenoszącego proboszcza wbrew jego woli, w którym winien określić termin, po upływie, którego nastąpi zawakowanie parafii ${ }^{113}$. Dekret biskupa winien być wydany na piśmie, zawierać motywy przeniesienia i aby powodował skutki prawne winien być odpowiednio doręczony ${ }^{114}$. Proboszcz po otrzymaniu dekretu jest zobowiązany do opuszczenia dotychczasowej parafii i objęcia nowego urzędu w terminie wyznaczonym w dekrecie. Gdyby proboszcz nie opuścił parafii biskup po użytecznym upływie tego terminu powinien ogłosić wakat parafii ${ }^{115}$. Skutki wydania przez biskupa definitywnego dekretu o zawakowaniu parafii z powodu niepodporządkowania się proboszcza nakazowi przeniesienia są

\footnotetext{
${ }^{111}$ Por. KPK/83, kan. 1750 w kontekście kan. $1742 \S 2$.

112 Por. J. KRukowski, Prawo administracyjne..., s. 423.

${ }^{113}$ Por. KPK/83, kan. 1751, $\$ 1$.

${ }^{114}$ Por. TAmże, kan. 55 i kan. 56.

${ }^{115}$ Por. TAmżE, kan. 1751, $₫ 2$.
} 
takie same jak dekretu dotyczącego jego usunięcia. Wskazane jest, aby biskup przed wydaniem takiego dekretu upewnił się, czy proboszcz otrzymał dekret o przeniesieniu i czy nie zaistniała przyczyna usprawiedliwiająca nieobjęcie przez niego nowego urzędu ${ }^{116}$. Niektórzy ustawodawcy synodalni stanowią w tym względzie konkretne przepisy zapewniające biskupowi swobodę przenoszenia i usuwania proboszczów przy uwzględnieniu konieczności zaradzenia potrzebom dobra duchowego wiernych i zachowaniu naturalnej i kanonicznej sprawiedliwości ${ }^{117}$ lub swobodę mianowania i odwoływania proboszczów ${ }^{118}$, a gdy proboszcz odmawia przeniesienia wówczas mają zastosowanie procedury specjalne ${ }^{119}$.

\subsection{Skutki przeniesienia proboszcza}

Prawodawca kodeksowy określa także skutki wydania przez biskupa definitywnego dekretu o wakacie parafii w procedurze przenoszenia proboszcza. Są one takie same jak dekretu usunięcia proboszcza z zachowaniem słuszności kanonicznej ${ }^{120}$, co oznacza, że biskup winien postępować z zachowaniem roztropności pastoralnej mając na uwadze prawdę, że najwyższym prawem w Kościele jest zbawienie dusz. Przeniesiony proboszcz winien przede wszystkim powstrzymać się od wykonywania zadań proboszcza w parafii, z której został przeniesiony. Ponadto powinien opuścić dom parafialny chyba, że biskup zezwoliłby mu na dalsze przebywanie w nim, wyłącznie z racji choroby ${ }^{121}$. Przeniesiony proboszcz powinien także przekazać wszystko, co należy do parafii temu, komu biskup parafię powierzył ${ }^{122}$. W sytuacji, w której proboszcz uważa się za pokrzywdzonego dekretem

\footnotetext{
${ }^{116}$ Por. J. Krukowski, Prawo administracyjne..., s. 424.

${ }^{117}$ Por. Pierwszy Synod Diecezji Warszawsko-Praskiej, st. $124 \$ 3$; Pierwszy Synod Diecezji Toruńskiej, st. 181, s. 56; I Synod Diecezji Łomżyńskiej, st. 164, s. 69.

${ }^{118}$ Por. Synod Archidiecezji Przemyskiej, st. $196 \$ 2$, s. 67.

${ }^{119}$ Por. I Synod Diecezji Łomżyńskiej, st. 164, s. 69.

${ }^{120}$ Por. KPK/83, kan. 1752.

${ }^{121}$ Por. TAmżE, kan. $1747 \$ 2$.

122 Por. TAmżE, kan. $1747 \$ 1$.
} 
biskupa może wnieść rekurs hierarchiczny ${ }^{123}$ zgodnie z przewidzianą procedurąa ${ }^{124}$. Możliwość rekursu jest przy przenoszeniu proboszcza $\mathrm{w}$ trybie administracyjnym taka sama jak przy jego usuwaniu, takie same są też skutki rekursu, tzn. parafia nie może być obsadzona na stałe, ale biskup diecezjalny powinien ją powierzyć na pewien czas, czyli do rozstrzygnięcia rekursu administratorowi parafii ${ }^{125}$. Zanim jednak wniesie rekurs powinien on złożyć na piśmie w ciągu $10 \mathrm{dni}$ użytecznych prośbę do biskupa, który wydał dekret, o jego poprawienie lub odwołanie ${ }^{126}$.

\section{Pozbawienie urzędu}

Jak wspomniano wyżej pozbawienie urzędu, w tym także urzędu proboszcza, ma charakter karny i jest to jedna z kar ekspiacyjnych ${ }^{127}$, którą prawodawca przewiduje za ciężkie przestępstwa ${ }^{128}$. Karę tę można wymierzyć także za inne przestępstwa, jeśli przez sędziego lub kompetentnego przełożonego zostanie uznana za karę sprawiedliwą. Jest ona więc wymierzana przez władzę kompetentną do powierzenia danego urzędu lub przez jej sąd na czas określony lub nieokreślony zgodnie z przepisami prawa. Pozbawienie urzędu na stałe może być wymierzone tylko na drodze sądowej, czyli w procesie karnym ${ }^{129}$. $\mathrm{Na}$ czas określony może być dokonane na mocy dekretu. Przeciw wyrokowi lub dekretowi pozbawiającemu urzędu przysługuje prawo apelacji lub rekursu ze skutkiem zawieszającym. Powoduje on zawieszenie władzy związanej z urzędem ${ }^{130}$. Jednak $\mathrm{z}$ chwilą, gdy dekret

\footnotetext{
${ }^{123}$ Por. Jan PaweŁ II, Konstytucja Pastor Bonus, art. 93.

${ }^{124}$ Por. KPK/83, kan. 1732-1739.

${ }^{125}$ Por. T. Pieronek, Administracyjne usunięcie..., s. 42.

${ }^{126}$ Por. KPK/83, kan. 1734.

${ }^{127}$ Por. TAmże, kan. $1336 \$ 1$, n. $2^{\circ}$. Kara ta nie może być karą latae sententiae.

${ }^{128}$ Por. Niekiedy prawodawca wyraźnie o nich wspomina (por. KPK/83, kan. 1364 $\$ 1$; kan. 1387; kan. $1389 \$ 1$; kan. $1394 \$ 1$; kan. 1396; kan. 1397; kan. 1457. Przy karach powodujących wydalenie ze stanu duchownego, np. kan. 1367, kan. $1370 \$ 1$, kan. 1395 usunięcie $\mathrm{z}$ urzędu następuje mocą prawa.

${ }^{129}$ Por. KPK/83, $1342 \$ 2$. Zgodnie z procedura przewidzianą w kan. 1717-1731.

${ }^{130}$ Por. TAmżE, kan. $143 \$ 2$.
} 
pozbawienia urzędu staje się wykonalny lub wyrok przeszedł w stan rzeczy osądzonej, usunięty traci wszelkie prawa związane z urzędem i zostaje uwolniony od obowiązków do niego przypisanych, a urząd staje się wakujący ${ }^{131}$. W tej sytuacji władza nie ma prawnego obowiązku zapewnienia utrzymania osobie pozbawionej urzędu, zaś obowiązek moralny podlega osądowi tejże władzy.

Należy zauważyć, że także przy pozbawieniu urzędu proboszcza na drodze postępowania procesowego ustawy partykularne również nie zawierają dodatkowych przepisów, ponieważ to postępowanie jest określone procedurą sądową przewidzianą w odnośnych kanonach Kodeksu prawa kanonicznego.

\section{5. Śmierć proboszcza}

Śmierć jest najbardziej naturalnym i oczywistym sposobem utraty urzędu kościelnego w tym urzędu proboszcza. Fakt śmierci proboszcza powinien być potwierdzony stosownym dokumentem, stwierdzającym zgon ${ }^{132}$. Na wypadek śmierci każdy kapłan, a szczególnie proboszcz, jest zobowiązany przez prawo partykularne do sporządzenia testamentu ${ }^{133}$, który powinien spełniać wymogi prawa cywilnego. W związku z tym statuty synodalne, najczęściej w aneksach,

\footnotetext{
${ }^{131}$ Por. R. Sobański, Utarta urzędu..., s. 286.

${ }^{132}$ Dokumentem stwierdzającym zgon osoby fizycznej jest akt zgonu sporządzony przez kierownika Urzędu Stanu Cywilnego właściwego ze względu na miejsce śmierci osoby, Ustawa z dnia 28 listopada 2014 r. Prawo o aktach stanu cywilnego, art. 16 i 92 nn, Dz. U. 2014 poz.1741. Szerzej na ten temat por. H. WiTCzAK, A. KAWAŁKo, Prawo spadkowe, Warszawa 2008, s. 18-19.

${ }^{133} \mathrm{~W}$ polskim prawie synodalnym spotyka się różne rozwiązania w tej materii, np. zobowiązanie do sporządzenia testamentu po czterdziestym roku życia, albo po objęciu urzędu albo też odnawianie ostatniej woli, co pięć lat. Podobnie miejsce przechowywania testamentu jest różnorodne. Najczęściej wskazywanym miejscem jest kuria diecezjalna, ale też i urząd dziekański lub obydwa miejsca, zależnie od okoliczności czy pełnionej funkcji (por. Synod Archidiecezji Przemyskiej, st. 214 $\S 2$ i 3, s. 74; Pierwszy Synod Diecezji Warszawsko-Praskiej, st. 70, s. 64; I Synod Archidiecezji Białostockiej, st. 60, s. 30; IV Synod Diecezji Tarnowskiej, st. $432 \$ 1-3$, s. 196; Pierwszy Synod Diecezji Kaliskiej, st. 300 i 301, s. 56; Pierwszy Synod Diecezji Toruńskiej, st. 467, s. 158; Drugi Synod Częstochowski, st. 3.3.21, s. 195).
} 
zawierają pouczenia w tej materii. Są to niekiedy instrukcje dotyczące sposobu sporządzania testamentu, a nawet gotowe wzor $y^{134}$. Należy zauważyć, że są to uzasadnione działania ustawodawców diecezjalnych, bowiem w praktyce brak ostatniej woli kapłana, a szczególnie proboszcza może powodować liczne komplikacje, a nawet zgorszenia z powodu chęci wzbogacenia się naturalnych spadkobierców, nawet kosztem dóbr parafii. Pewną wątpliwość mogą budzić gotowe wzory testamentów, w których wskazuje się konkretne cele, na które testator powinien przeznaczyć swój majątek. Nasuwa się pytanie czy chodzi tu o bezprawną ingerencję ustawodawców diecezjalnych w naturalne prawo własności, czy raczej jest to próba kształtowania pewnego stylu życia kapłańskiego i dysponowania swoim majątkiem ${ }^{135}$.

Prawodawca kodeksowy dąży do tego, aby zapewnić ciągłość sprawowania władzy wynikającej z urzędu, w tym przypadku proboszcza, aby jak najszybciej ktoś inny przejął tymczasową odpowiedzialność za parafię. Stąd też biskup diecezjalny, w sytuacji wakatu parafii, powinien jak najszybciej mianować administratora parafii, czyli kapłana, który by zastępował proboszcza zgodnie z przepisami prawa ${ }^{136}$. Co więcej, aby parafia nawet na krótki czas nie była pozbawiona pasterza tenże prawodawca stanowi, że do czasu ustanowienia administratora parafii jej zarząd przejmuje tymczasowo wikariusz parafialny, a gdy jest ich kilku, najstarszy nominacją. W parafii, gdzie nie ma wikariusza obowiązek ten przechodzi na proboszcza wyznaczonego przez prawo partykularne ${ }^{137}$. Ma to na celu nie tylko zabezpieczenie troski duszpasterskiej, ale też i ochronę stanu materialnego parafii. Również niektórzy ustawodawcy partykularni w statutach synodalnych, czy też w aneksach do nich, podejmują troskę, aby w przypadku śmierci proboszcza parafia nie była pozbawiona pasterza i przypominają

\footnotetext{
${ }^{134}$ Por. Aby byli jedno. Drugi Synod Diecezji Sandomierskiej, s. 467-470; Synod Archidiecezji Przemyskiej, s. 407-410; Synod Diecezji Ełckiej, s. 201-204, Pierwszy Synod Diecezji Kaliskiej, s. 287-289; I Synod Archidiecezji Białostockiej, s. 277-281.

${ }^{135}$ Por. Pierwszy Synod Diecezji Kaliskiej, st. 303, s. 57.

${ }^{136}$ Por. KPK/83, kan. 539; I Synod Archidiecezji Białostockiej, st. 61, s. 30.

${ }^{137}$ Por. TAmże, kan. $541 \$ 1$. Szerzej na ten temat por. E. SzTAFrowski, Pozycja proboszcza..., s. 67.
} 
normy kodeksowe o tymczasowym zarządzie parafią, a niekiedy wprost stanowią, że w sytuacji braku w parafii wikariusza, tymczasowy zarząd przejmuje dziekan, a w razie jego nieobecności wicedziekan ${ }^{138}$. Dziekan spełnia ważną rolę przy śmierci proboszcza. To właśnie do jego zadań należy powiadomienie władzy diecezjalnej o śmierci proboszcza. On też odpowiada za zabezpieczenie dokumentów parafialnych, zwłaszcza ksiąg parafialnych oraz majątku parafialnego i osobistego zmarłego proboszcza. Niekiedy on też jest odpowiedzialny za przygotowanie pogrzebu, powiadomienie kapłanów dekanatu o miejscu i czasie pogrzebu proboszcza. Może też być on wyznaczony z urzędu na wykonawcę testamentu, o ile zmarły proboszcz nie rozporządził inaczej ${ }^{139}$.

\section{Upływ czasu}

Utrata urzędu proboszcza może nastąpić również na skutek upływu czasu, w przypadku, gdy był on mianowany przez biskupa diecezjalnego na określoną kadencję zgodnie z przepisami prawa partykularnego. Prawodawca kodeksowy modyfikując zasadę stałości urzędu proboszcza wprowadził możliwość mianowania proboszczów na czas określony, co może się dokonać za zgodą Konferencji Biskupów ${ }^{140}$. Chodzi tu przede wszystkim o nominację na określoną

\footnotetext{
${ }^{138}$ Por. Synod Archidiecezji Przemyskiej, s. 352; Synod Diecezji Łowickiej, st. $101 \$ 1$, s. 37; Pierwszy Synod Diecezji Toruńskiej, st. 187, s. 57 i s. 298; Uchwały XLII Synodu Płockiego, st. 214, s. 42; Pierwszy Synod Diecezji Kaliskiej, st. 41, s. 17.

${ }^{139}$ Por. Synod Archidiecezji Przemyskiej, s. 350; Aby byli jedno. Drugi Synod Diecezji Sandomierskiej, st. 38, s. 167; Drugi Synod Diecezji Włocławskiej, st. 327, s.95; III Synod Diecezji Łódzkiej, art. 49, s. 32; Pierwszy Synod Diecezji Toruńskiej, s. 298. ${ }^{140} \mathrm{~W}$ Kościele polskim upoważnienie biskupów diecezjalnych do mianowania proboszczów na czas określony było już dyskutowane podczas II Polskiego Synodu Plenarnego (1991-1999) i nie zostało sfinalizowane. Ponowną dyskusję nad kadencyjnością proboszczów podjęto podczas obrad Rady Stałej Konferencji Episkopatu Polski i biskupów diecezjalnych w Częstochowie w dniu 26 sierpnia 2008 r. Wstępnie padły propozycje, by kadencja trwała od 5 do 7 lat. W dyskusji z jednej strony padały argumenty o tym, że parafie potrzebują elementu stabilności, ciągłości i trwałości a z drugiej strony wskazywano na to, że zmiany na stanowisku proboszcza mogą być inspirujące zarówno dla parafii jak i samego kapłana.
} 
kadencję lub wskazany w dekrecie nominacyjnym czas sprawowania urzędu ${ }^{141}$. Taka nominacja proboszcza oznacza, że z upływem określonego czasu ustaje jego władza w konkretnej parafii, która staje się parafią wakującą. Biskup może przedłużyć nominację na następną kadencję, ale też może jej nie przedłużyć. W takiej sytuacji biskup nie musi podejmować żadnych procedur, bowiem utrata urzędu następuje $\mathrm{z}$ chwilą upływu terminu, zgodnie $\mathrm{z}$ dekretem nominacyjnym ${ }^{142}$. W polskim prawie synodalnym znajdują się różne zapisy w tej materii. Niektórzy ustawodawcy przyjmują mianowanie proboszczów na czas nieokreślony ${ }^{143}$, albo zasadniczo na czas nieokreślony, a na czas określony tylko wtedy, jeżeli sytuacja i okoliczności za tym przemawiają ${ }^{144}$, albo zalecają by czas posługi proboszczowskiej w jednej parafii nie był zbyt długi ${ }^{145}$, jeszcze inni powołują się wprost na postanowienia II Polskiego Synodu Plenarnego ${ }^{146}$ lub na wskazania tegoż Synodu i Wskazania Konferencji Episkopatu Polski ${ }^{147}$. Inni natomiast pomijają kwestię kadencyjności nie stanowiąc żadnych przepisów w tej materiii ${ }^{148}$.

\section{Skutki utraty urzędu proboszcza}

Wszystkie wymienione wyżej formy i sposoby utraty urzędu proboszcza, oprócz wielu szczegółowych skutków określonych prawem, zwłaszcza przy jego usunięciu lub przeniesieniu, które zostały już wyżej omówione, powodują podstawowy skutek prawny, jakim jest wakat parafii. Wakat jest sytuacją nadzwyczajną, która burzy normalne jej funkcjonowanie i powoduje zaburzenia w życiu parafialnym. Stąd

\footnotetext{
${ }^{141}$ Por. KPK/83, kan. 522.

${ }^{142}$ Por. J. Krukowski, Parafie, proboszczowie i wikariusze parafialni, w: Komentarz do Kodeksu Prawa Kanonicznego, t. II/1, red. J. Krukowski, Pallottinum 2005, s. 422.

${ }^{143}$ Por. I Synod Diecezji Łomżyńskiej, st. 157, s. 68.

${ }^{144}$ Por. Pierwszy Synod Diecezji Kaliskiej, st. 27, s. 14.

${ }^{145}$ Por. Drugi Synod Częstochowski, st, 3.3.15, s. 194.

${ }^{146}$ Por. Synod Archidiecezji Przemyskiej, st. 204, s. 70.

${ }^{147}$ Por. Pierwszy Synod Diecezji Warszawsko-Praskiej, st. $124 \$ 4$, s. 82.

${ }^{148}$ Por. Pierwszy Synod Diecezji Toruńskiej, st. 179 nn.; I Synod Archidiecezji Białostockiej, st. 48 nn.; Uchwały XLII Synodu Płockiego, st.192 nn.
} 
też prawodawcy kościelnemu zależy, aby parafia wskutek wakatu nie pozostawała przez dłuższy czas bez pełnoprawnego pasterza i zarządcy, stąd stanowi, aby powierzenie urzędu duszpasterskiego nie było odciągane w czasie bez ważnej przyczyny ${ }^{149}$. Z tego samego powodu na wypadek wakatu lub przeszkodzenia stolicy biskupiej, trwających dłużej niż jeden rok, nominację nowego proboszcza zleca administratorowi diecezji ${ }^{150}$. W sytuacji wakatu parafii, zanim zostanie mianowany nowy proboszcz, biskup diecezjalny powinien jak najszybciej mianować administratora parafii ${ }^{151}$, który ma te same obowiązki i posiada te same uprawnienia, co proboszcz, chyba że biskup postanowi inaczej ${ }^{152}$, a nawet, o czym była już wyżej mowa, zanim zostanie ustanowiony administrator parafii jej zarząd przejmuje tymczasowo wikariusz parafialny, a gdy jest ich kilku, najstarszy nominacją lub dziekan w przypadku parafii jednoosobowych.

\section{Zakończenie}

Z urzędem proboszcza istotowo związana jest pasterska troska o powierzoną mu wspólnotę wiernych. Oznacza to, że do spełnienia swej misji został on powołany na podstawie uczestniczenia razem z biskupem w kapłaństwie Chrystusa i powierzonego sobie urzędu. $\mathrm{Z}$ tej racji proboszcz cieszy się w prawie określoną stabilnością, która ma na celu ścisłe i trwałe związanie go z powierzonym mu ludem, mobilizowanie go do ofiarnej i owocnej pracy duszpasterskiej. Jednakże stabilność ta nie ma charakteru bezwzględnego. Stąd też prawodawca kodeksowy zniósł urząd proboszcza nieusuwalnego, ponadto proboszcz swego urzędu nie sprawuje w sposób autonomiczny i bez żadnej zależności, lecz z upoważnienia biskupa diecezjalnego, który z mocy prawa Bożego jest pasterzem Kościoła partykularnego. Ze względu na dobro wiernych albo konieczność lub pożytek Kościoła albo też inne okoliczności życiowe tenże prawodawca przewiduje

\footnotetext{
${ }^{149}$ Por. KPK/83, kan. 151.

${ }^{150}$ Por. TAmże, kan. 525 20.

${ }^{151}$ Por. TAmże, kan. 539; I Synod Archidiecezji Białostockiej, st. 61, 30.

${ }^{152}$ Por. TAmże, kan. 540.
} 
kilka sposobów utraty urzędu proboszcza. Na podstawie norm ogólnych urząd kościelny, w tym także urząd proboszcza, traci się po upływie czasu, po osiągnięciu określonego prawem wieku, na skutek rezygnacji, przeniesienia, usunięcia, a także pozbawienia. Naturalną przyczyną utraty każdego urzędu kościelnego jest śmierć osoby go piastującej. Pomimo tych postanowień prawodawca kościelny dla urzędu proboszcza odrębnie określa sposoby utraty, zaliczając do nich usunięcie lub przeniesienie dokonane zgodnie z przepisami prawa, zrzeczenie się dla słusznej przyczyny oraz upływ czasu. Szczególnie w przypadku usunięcia lub przeniesienia przewiduje specjalne procedury administracyjne. Chodzi nie o karne, lecz czysto administracyjne usunięcie lub przeniesienie proboszcza do innej parafii lub na inny urząd, ze względu na dobro wiernych. Wyodrębnienie tych dwóch procedur, które są znane w Kościele od dawna, wynika przede wszystkim z doniosłej roli, jaką w życiu wspólnoty parafialnej ma do spełnienia proboszcz oraz z faktu stałości jego urzędu. Procedury te mają na celu wyeliminowanie sytuacji, w której określone nadużycia ze strony proboszcza mogłyby pozbawić wiernych dóbr duchowych, do których mają prawo, nie pomijając też dobra proboszcza. Wszystkie sposoby utraty urzędu proboszcza, oprócz skutków szczegółowych określonych przez prawodawcę, powodują wakat parafii.

\section{Loss of parish-priest's office}

The pastoral care for the community of the faithful entrusted to parish-priest is essentially connected with the office of the pastor. This means that the parish priest is called to fulfill his mission because of his participation in the priesthood of Christ and the office entrusted to him by the bishop. Therefore, he performs this office not autonomously and without any dependence, but under the authority of the diocesan bishop, who, by virtue of God's law, is a shepherd of the particular Church. For the sake of the faithful, the church legislator foresees several ways of losing the office of parish priest.

The author in this article discusses this very complex issue. Based on general norms, the church office, including the office of a parish priest, is lost after the lapse of time, after reaching the legal age, because of resignation, 
transfer, removal and deprivation. The natural reason for the loss of every church office is the death of the person holding it. Despite these provisions, the church legislator for the office of the parish priest separately determines the ways of loss, including the removal or transfer made in accordance with the law, waiver for a just cause and the passage of time. Particularly in the event of removal or transfer, it provides for special administrative procedures. The separation of these two procedures is primarily due to the important role that the parish priest has to fulfill in the life of the church community and the fact of the durability of his office. The role of these procedures is elimination of the possible abuses by the priest, which could deprive the parishioners of the spiritual goods to which they are entitled, without omitting the good of the priest. All ways of losing the office of parish priest, apart from the particular effects specified by the legislator, result in the vacancy of the parish.

SŁOWA KLUCzowe: urząd kościelny; utrata urzędu; proboszcz; procedura; prawodawca kościelny; skutki prawne

KEYWORDS: church office; loss of the office; pastor; legal procedures; church legislator; effects legal

\section{Nota o Autorze}

Ks. PROF. DR HAB. JózeF WROCEŃSKI - kapłan Zgromadzenia Księży Sercanów, profesor nauk prawnych Wydziału Prawa Kanonicznego Uniwersytetu Kardynała Stefana Wyszyńskiego w Warszawie. W latach 1999-2005 prodziekan, a w latach 2005-2012 dziekan Wydziału; kierownik Katedry Ustroju Kościoła i Kanonicznych Form Życia Konsekrowanego. Specjalista z zakresu kanonicznego prawa osobowego; zajmuje się również strukturą wewnętrzną Kościoła i jego relacjami z państwem. Autor licznych publikacji. Redaktor Naczelny wydziałowego czasopisma „Prawo Kanoniczne” UKSW, Zastępca Redaktora Naczelnego czasopisma „Kościół i Prawo” KUL. 